\title{
Geochemical fractionation of heavy metals in sediments of the Tapi estuary
}

\author{
R. J. Krupadam,* P. Smita and S. R. Wate \\ National Environmental Engineering Research Institute, Nehru Marg, NAGPUR-440 020, India
}

(Received June 6, 2005; Accepted May 1, 2006)

\begin{abstract}
Sequential extraction was used to study the operationally determined chemical forms of $\mathrm{Co}, \mathrm{Cr}, \mathrm{Cu}, \mathrm{Ni}, \mathrm{Pb}$ and $\mathrm{Zn}$ and their spatial distribution in the sediments of the Tapi estuary. It was found that oxidizable binding fraction was the most important phase for binding of all metals followed by Fe-Mn oxide and carbonate fractions. Zn bound to the Fe-Mn oxide fraction had a significant relationship with reducible $\mathrm{Mn}$ and reducible Fe concentrations suggesting that Fe-Mn oxides may be the main carriers of $\mathrm{Zn}$ from the fluvial environment to the estuarine body. The $\mathrm{Zn}$ bound to the Fe-Mn oxides and $\mathrm{Cu}$ bound to the oxidizable fraction showed a general distinctive decrease from the middle of the estuary (ES-3) to sea mouth (ES-5) and from upstream ES-2 to the mouth of the estuary (ES-2). Zn, Pb, and Cr were not correlated with bottom layers and had a high enrichment factor (up to 60 times) representing the influence of anthropogenic activities and thus are the main precursors of metal pollution. The average $\mathrm{I}_{\text {geo }}$ of six metals in the sediments from the middle of the estuary is 3.67 and is larger than the estuary mouth (1.24) and seaside sampling locations (2.33). This suggests that the middle of the estuary is strongly contaminated with heavy metals. Interestingly higher enrichment in the sediments is not linearly related to toxicity response factor which may be due to metal immobilization.
\end{abstract}

Keywords: geochemical fractionation, heavy metals, sediments, pollution, estuary

\section{INTRODUCTION}

The widespread use of heavy metals in industries ranging from large-scale mining to intensive agriculture has resulted in a variety of heavy metals being released into the environment with concentrations in excess of the natural background levels (De Groot et al., 1976; Dryssen and Wedborg, 1980). The potential environmental damage might be comparatively small if these metals are ultimately fixed in sediments and pore-water concentrations are limited by their solubility (Zoumis et al., 2001). Information on the total concentrations of metals alone is not sufficient to assess the environmental impact of polluted sediments because heavy metals are present as easily exchangeable metal carbonates, oxides, sulfides, organometallic compounds, ions in the crystal lattice of minerals etc. which determine their mobilization capacity and bioavailability (Gupta and Chen, 1975; SotoJimenez et al., 2003). It is necessary to identify and quantify the forms in which a metal is present in sediments to gain a more precise understanding of the potential and actual impacts of elevated concentrations, and to evaluate processes of downstream transport, deposition and release under changing environmental conditions ( $\mathrm{Li}$ et $a l ., 2000)$. The dominant geochemical processes responsible for the exchange of metals at the water-sediment

*Corresponding author (e-mail: rjkrupadam@yahoo.co.uk)

Copyright @ 2006 by The Geochemical Society of Japan. interface are adsorption and precipitation (Salomons and Forstner, 1984; Wang et al., 1997). Fe and Mn oxides and organic matter either as bulk phases or as coatings of mineral particles are the main binders in sediments (Tessier et al., 1980). Binding fractions of heavy metals in the sediments can be divided into five groups: exchangeable, carbonates, hydroxides, organic and residuals. It is intended that at each step of the analytical scheme, samples be exposed to the action of an extractant, which solubilizes a specific component and its associated metals. The procedures assume that one reagent attacks a well-defined component only, without affecting the remaining fractions (i.e., it is selective) and that there are no problems with re-adsorption of the already solubilized elements.

In the present study, ecological risk due to heavy metals in the estuary has been evaluated with reference to nearby industrial establishments generating a huge quantity of metallic wastes including spent catalyst (i.e., 150200 Metric Tons per annum). An assessment has been made based on a sequential extraction procedure to understand the binding fractions and mobility of metals to the surrounding environment. This study investigates the influence of anthropogenic activities on metal binding and their chemical control in the estuarine sediments. The link between geoaccumulation and ecological risk has been examined to gain insight into the processes affecting the representation of pollution magnitude in terms of toxicity of heavy metals. 


\section{Methodology}

\section{Study area}

The study area is situated between $68^{\circ} 30^{\prime}$ to $70^{\circ} 45^{\prime} \mathrm{E}$ longitude and $22^{\circ} 18^{\prime}$ to $23^{\circ} 25^{\prime} \mathrm{N}$ latitude. The Tapi estuary is a tidal estuary originating in the Multai Ghats in Betour district of Madhya Pradesh (India) at an elevation of $750 \mathrm{~m}$. The $720 \mathrm{~km}$ long river, after passing through three states i.e., Madhya Pradesh, Maharashtra and Gujarat, discharges into the Gulf of Kambhat (Cambay), North-West coast of India, near Hazira. In its upper reaches, the river receives discharge from 14 main tributaries, 4 on the right bank and 10 on the left bank, of which the Purna and the Girna are the most important, accounting for $45 \%$ of the total catchment area of 65,145 $\mathrm{km}^{2}$.

Owing to the topographical characteristics, the region shows variable climate with lowest temperatures (10$14^{\circ} \mathrm{C}$ ) occurring in winter while the higher temperatures $\left(37-48^{\circ} \mathrm{C}\right)$ occur in summer. The average salinity at the mouth is 30-32 parts per thousand (ppt) and decreases rapidly in the upstream direction, with a decrease of 10 ppt occurring within $10 \mathrm{~km}$ from the mouth, while a further 10 ppt decrease occurs in the next $6-7 \mathrm{~km}$. This steep salinity gradient results in the salinity falling to below $0.1 \mathrm{ppt}$ within a distance of $30 \mathrm{~km}$ from the mouth. The area receives, on an average, $950 \mathrm{~mm}$ of rainfall of which $85 \%$ occurs during the southwest monsoon (June to September). The estuary also receives an annual average river runoff of $7,686 \times 10^{6} \mathrm{~m}^{3}$, with annual ground water flow of $18,000 \times 10^{6} \mathrm{~m}^{3}$.

About $71 \%$ of the total population of $15,000,000$ of the basin is rural with no sewage and sewerage facilities. The urban population is spread over 37 cities and towns. The overall population density is $208 \mathrm{~km}^{-2}$. A major part of the basin $(62 \%)$ is predominantly agricultural while $26.6 \%$ of the area is under forest cover. The rest of the land is classified as non-arable and utilized for industrial activities and human settlement. There are 93 large and medium scale industrial units in the basin, plus innumerable small-scale units. The annual flow of wastes (domestic, industrial and agricultural) is estimated to be of the order of $4,026 \times 10^{6} \mathrm{~m}^{3}$. Chemical fertilizer is used in agricultural activities at an average rate of $110-113 \mathrm{~kg}$ $\mathrm{ha}^{-1}$ (CPCB , 1994). Types of industries include: engineering, thermal power, food and beverages, textiles, chemical and metallurgical.

\section{Sampling and analysis}

Sediment core samples were collected from estuarine region as marked in Fig. 1 using square PVC tubing (6 $\mathrm{cm} \times 6 \mathrm{~cm} \times 10 \mathrm{~cm}$ ) during October-November, 2004 . Cores were opened in the laboratory and samples stored in a refrigerator. Before each analysis the samples were oven-dried at $50^{\circ} \mathrm{C}$ until no further weight loss was observed. To understand geoaccumulation of metals as a function of vertical distribution, the sediment cores were divided into four parts. They are (i) $0-20 \mathrm{~cm}$, which is a geochemically active zone (ii) $20-30 \mathrm{~cm}$, (iii) $30-40 \mathrm{~cm}$ and (iv) 40-100 cm. Each part of the sediment core was divided into 3 equal parts i.e., 12 sediment core samples for a sediment core. Over all, 300 sediment segments were analyzed. The dried samples were stored in desiccators (Yu et al., 2001). Prior to grain size analysis, carbonates (including shell fragments and other acid soluble detritus fragments) were removed by dissolution in $10 \%$ hydrochloric acid. Organic carbon was removed from the samples by loss-on-ignition at $585^{\circ} \mathrm{C}$ for $2-3 \mathrm{~h}$ (Dean, 1974).

Grain size analysis was carried out using the Galai Cis-1 Laser particle size analyzer (Jantschik et al., 1992) after removal of particles greater than $1 \mathrm{~mm}$ in diameter by sieving. The weight of this fraction was recorded and included in the final percentage sand, silt and clay textural calculations. Four phases including exchangeable, carbonates, Fe-Mn oxides and organic matter contained in sediment matrices of the air-dried sediment samples were analyzed. Carbonates were analyzed using the approximate gravimetric method (Raad, 1978) while organic matter was determined using Walkley-Black wet combustion method (Nelson and Sommers, 1982).

Since the primary concern was pollution levels within the sediment, sample preparation and digestion techniques were chosen such that they would extract heavy metals bound to all particle sizes. A selective sequential extraction procedure (SEP) was followed to determine heavy metal retention profiles (Tessier et al., 1979; Yong et al., 2000). Details of the SEP are described as follows: (i) exchangeable fraction $-3 \mathrm{~g}$ of the air-dried sediment sample is extracted with $20 \mathrm{ml}$ of $1 \mathrm{M} \mathrm{NH}_{4} \mathrm{OAc}(\mathrm{pH} 7.0$ ) for $30 \mathrm{~min}$ at room temperature $\left(25-30^{\circ} \mathrm{C}\right)$ with agitation, (ii) carbonate bound fraction-the residue from the exchangeable fraction is extracted with $20 \mathrm{ml}$ of $1 \mathrm{M}$ $\mathrm{NaOAc}$ (adjusted to a $\mathrm{pH}$ of 5.0 with HOAc) for $5 \mathrm{~h}$ at room temperatures with agitation, (iii) Fe-Mn oxides bound fraction - the residue from carbonates fraction is extracted with $20 \mathrm{ml}$ of $0.04 \mathrm{M} \mathrm{NH}_{2} \mathrm{OH} . \mathrm{HCl}$ in $25 \%(\mathrm{v} /$ v) acetic acid for $6 \mathrm{~h}$ in a water bath $\left(96^{\circ} \mathrm{C}\right)$ and with occasional agitation, (iv) organic matter/sulfide bound fraction - the residue from Fe-Mn oxides is extracted with $5 \mathrm{ml}$ of $0.1 \mathrm{~N} \mathrm{HNO}_{3}$ and $10 \mathrm{ml}$ of $30 \% \mathrm{H}_{2} \mathrm{O}_{2}$ for $5 \mathrm{~h}$ in a water bath $\left(85^{\circ} \mathrm{C}\right)$ and with occasional agitation. After cooling, the extracted solution is then added to $15 \mathrm{ml}$ of $3.2 \mathrm{M} \mathrm{NH}_{4} \mathrm{OAc}$ in $20 \% \mathrm{HNO}_{3}$ and shaken continuously for $30 \mathrm{~min}$ at room temperature. After each extraction step samples were centrifuged at $9500 \mathrm{rpm}$ for $20 \mathrm{~min}$ to separate the extracts from solids. The resultant extracts were used for determining the concentrations of $\mathrm{Co}, \mathrm{Cr}, \mathrm{Cu}$, $\mathrm{Ni}, \mathrm{Pb}$, and $\mathrm{Zn}$ by atomic absorption spectrometry. Atomic 


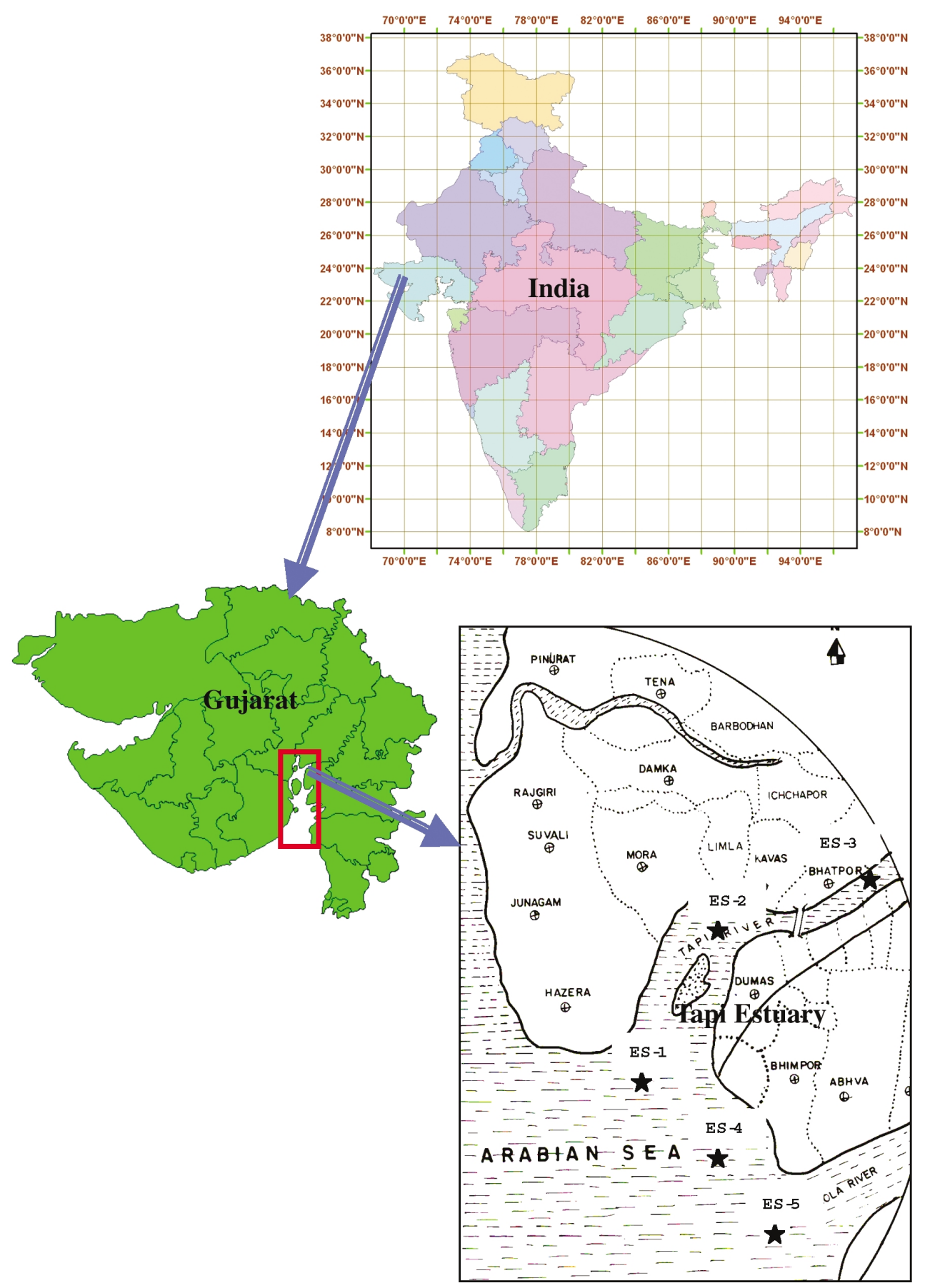

Fig. 1. Geographical location of the study area showing the sampling locations in the Tapi estuary.

Absorption Spectrometry (AAS) (Model: Perkin Elmer AAS 3100) was used to determine heavy metal concentrations. A blank digest, viz. Teflon bound containing only acid was analyzed from every batch of samples, as well as a repeat digest for every fifth sample to test for reproducibility. A standard reference material (IC-HRM2) was used to verify the accuracy of metal determination in the sequential extraction analysis ( $\mathrm{Li}$ et al., 2000). The recovery rates for heavy metals in the standard reference material were around $85-110 \%$. Moreover, cumulative concentrations of the metals in sediments were compared with the independent total concentration by digesting the same sample with a concentrated mixture of $\mathrm{HNO}_{3} /$ $\mathrm{HClO}_{4}$. The total recovery rates for metals in sediment 
Table 1. Statistical data of standard reference material (SRM) for heavy metals

\begin{tabular}{lcccrr}
\hline Heavy metal & $\begin{array}{c}\text { Certified values } \\
(\mathrm{mg} / \mathrm{kg})\end{array}$ & $\begin{array}{c}\text { Measured mean } \\
(\mathrm{mg} / \mathrm{kg})\end{array}$ & $\begin{array}{c}\mathrm{SD} \\
(\mathrm{mg} / \mathrm{kg})\end{array}$ & $\begin{array}{c}\mathrm{CV} \\
(\%)\end{array}$ & $\begin{array}{c}\mathrm{RE} \\
(\%)\end{array}$ \\
\hline $\mathrm{Pb}$ & 2.00 & 2.06 & 0.14 & 6.80 & -3.00 \\
$\mathrm{Cu}$ & 2.00 & 2.20 & 0.12 & 5.00 & -10.00 \\
$\mathrm{Zn}$ & 2.00 & 1.67 & 0.20 & 12.00 & 17.00 \\
$\mathrm{Cr}$ & 2.00 & 1.75 & 0.16 & 5.60 & 10.50 \\
$\mathrm{Co}$ & 2.00 & 1.81 & 0.13 & 7.20 & 9.50 \\
$\mathrm{Ni}$ & 2.00 & 2.10 & 0.12 & 5.50 & -9.00 \\
\hline
\end{tabular}

$S D=$ Standard Deviation $; C V=$ Coefficient of Variation $; R E=$ Relative Error .

samples were between $82-102 \%$. Blanks were also used for background correction and random error calculation. The precision and bias were generally $<10 \%$. Statistical analysis data for trace elements in the sediment SRM analyzed by AAS are given in Table 1 . The index of geoaccumulation was used to quantify the extent of heavy metal contamination associated with the sediment of Tapi estuary. The $\mathrm{I}_{\mathrm{geo}}$ was calculated using Müller's equation (Müller, 1979):

$$
\mathrm{I}_{\text {geo }}=\log _{2} \mathrm{C}_{\mathrm{n}} / 1.5 \mathrm{~B}_{\mathrm{n}}
$$

where $C_{n}$ represents the measured total concentration of metals in the fine-grained sediment fraction (clay or silt) $(\mathrm{mg} / \mathrm{kg}) ;$ and $\mathrm{B}_{\mathrm{n}}$ represents the geochemical background values of metals $(\mathrm{mg} / \mathrm{kg})$. For the analysis of the geochemical background values of heavy metals $\left(B_{n}\right)$, five uncontaminated surface sediments were collected from upstream of the Tapi River where both anthropogenic and industrial activities were absent which will represent geological background with reference to heavy metals. The total concentrations of various metals in the fine-grained fraction (clay or silt) $\left(\mathrm{C}_{\mathrm{n}}\right)$ of estuarine samples were estimated by the weighted mean of the five uncontaminated sites. By using the collected data, $I_{\text {geo }}$ values were calculated as per Müller's equation. In addition to the geoaccumulation index, an attempt was made to calculate enrichment factors to classify contamination level in the estuary sediment.

Enrichment factors were also determined to understand whether certain heavy metals were present in high concentrations relative to the concentrations in the earth's crust using the equation from Sposito et al. (1982). By considering aluminum as a conservative element, normalization of elemental concentrations was done in the following manner:

$$
\begin{aligned}
& \mathrm{EF}=\left[\mathrm{C}^{\mathrm{MX}}-\mathrm{C}^{\mathrm{NaX}}\left(\mathrm{C}^{\mathrm{M}} / \mathrm{C}^{\mathrm{Na}}\right) \mathrm{S}: \mathrm{C}^{\mathrm{MC}} \mathrm{C}_{-}{ }^{\mathrm{NaC}}\left(\mathrm{C}^{\mathrm{M}} / \mathrm{C}^{\mathrm{Na}}\right) \mathrm{S}\right] \\
& /\left[\mathrm{C}^{\mathrm{FeX}}-\mathrm{C}^{\mathrm{NaX}}\left(\mathrm{C}^{\mathrm{Fe}} / \mathrm{C}^{\mathrm{Na}}\right) \mathrm{S}: \mathrm{C}^{\mathrm{Fe}}-\mathrm{C}^{\mathrm{NaC}}\left(\mathrm{C}^{\mathrm{Fe}} / \mathrm{C}^{\mathrm{Na}}\right) \mathrm{S}\right]
\end{aligned}
$$

where superscripts $\mathrm{X}, \mathrm{S}, \mathrm{C}, \mathrm{M}$ refer to sediments, seawater, the earth's crust, and the element respectively. Elements with enrichment factors larger than one may be due to sources other than natural weathering of the earth's crust. In addition, strong correlations with aluminum and enrichment factors (close to one) represent elements present in sediments due to natural weathering.

With the aim of achieving a broader assessment of the Tapi estuary heavy metal pollution, in terms of ecological risks, a quantitative approach is needed. The use of $\mathrm{LC}_{50}$ tests as benchmarks to forecast the consequences of metal concentrations in water (pore-water) lacks the capability to couple the toxic effects to chronic exposures in complex dynamic systems. Hakanson (1980) developed a methodology to assess ecological risks for aquatic pollution control. The methodology is based on the assumption that the sensitivity of the aquatic systems depends on its productivity. This concept is in good agreement with the discussions and results presented in the present work. A bioproduction index (BPI) defined as the $\mathrm{N}$ or $\mathrm{P}$ content on the regression curve $\mathrm{N}$ or $\mathrm{P} \times \mathrm{IG}$ (organic matter content) for $\mathrm{IG}=10 \%$ is introduced to account for the sensitivity of the water body to toxicants. The potential ecological risk of a given contaminant according to Hakanson's (1980) is;

$$
\operatorname{Er}^{\mathrm{i}}=\operatorname{Tr}^{\mathrm{i}} * \mathrm{Cf}^{\mathrm{i}}
$$

where $\operatorname{Tr}^{\mathrm{i}}=$ the toxic-response factor for a given substance; $\mathrm{Cf}^{\mathrm{i}}=$ the contamination factor (the ratio between pre-industrial records in the sediments and present concentration values). The toxic-response factor $\operatorname{Tr}^{\mathrm{i}}$ that accounts for toxic requirement and the sensitivity requirement is described in Table 2.

The sum of the individual potential risks $\left(\mathrm{Er}^{\mathrm{i}}\right)$ is the potential risk for the water body:

$$
\mathrm{RI}=\sum \mathrm{Er}^{\mathrm{i}}=\sum \operatorname{Tr}^{\mathrm{i}} * \mathrm{Cf}^{\mathrm{i}} .
$$

In keeping with Hakanson (1980), the following termi- 
Table 2. Toxic response factor based Risk Indices for heavy metals

\begin{tabular}{lcrrrrr}
\hline Metal & $\operatorname{Tr}^{\mathrm{i}}$ value & \multicolumn{5}{c}{ RI } \\
\cline { 3 - 7 } & & ES-1 & ES-2 & ES-3 & ES-4 & ES-5 \\
\hline $\mathrm{Co}$ & $5 *(5)^{1 / 2}(\mathrm{BPF})^{1 / 2}$ & 90 & 80 & 159 & 284 & 583 \\
$\mathrm{Ni}$ & $5 *(5)^{1 / 2}(\mathrm{BPF})^{1 / 2}$ & 132 & 112 & 209 & 329 & 543 \\
$\mathrm{Cu}$ & $5 *(5)^{1 / 2}(\mathrm{BPF})^{1 / 2}$ & 63 & 75 & 420 & 670 & 560 \\
$\mathrm{Zn}$ & $1 *(5)^{1 / 2}(\mathrm{BPF})^{1 / 2}$ & 140 & 120 & 270 & 440 & 670 \\
$\mathrm{~Pb}$ & $5 *(5)^{1 / 2}(\mathrm{BPF})^{1 / 2}$ & 62 & 57 & 160 & 145 & 181 \\
$\mathrm{Cr}$ & $2 *(5)^{1 / 2}(\mathrm{BPF})^{1 / 2}$ & 80 & 95 & 116 & 170 & 250 \\
\hline
\end{tabular}

$R I<150$ - low ecological risk for the water body; $150<R I<300$ - moderate ecological risk for the water body; $300<R I<600-$ considerable ecological risk for the water body; RI > 600 -very high ecological risk for the water body.

Table 3. Physico-chemical Characteristics of surface core samples of the sediments

\begin{tabular}{|c|c|c|c|c|c|c|}
\hline Parameter & ES-1 & ES-2 & ES-3 & ES-4 & ES-5 & SRM \\
\hline $\mathrm{pH}$ & $6.3 \pm 0.2$ & $7.5 \pm 0.2$ & $8.1 \pm 0.1$ & $8.1 \pm 0.2$ & $8.2 \pm 0.1$ & $7.8 \pm 0.3$ \\
\hline Electrical conductivity $\left(\mathrm{mS} \mathrm{cm}^{-1}\right)$ & $2.38 \pm 0.27$ & $1.38 \pm 0.22$ & $1.11 \pm 0.24$ & $1.25 \pm 0.33$ & $0.42 \pm 0.29$ & $0.63 \pm 0.13$ \\
\hline \multicolumn{7}{|l|}{ Cations $\left(\mathrm{cmol} \mathrm{kg}^{-1}\right)$} \\
\hline $\mathrm{Na}^{+}$ & $2.16 \pm 0.14$ & $1.24 \pm 0.17$ & $2.73 \pm 0.11$ & $2.06 \pm 0.13$ & $1.16 \pm 0.11$ & $0.92 \pm 0.09$ \\
\hline $\mathrm{K}^{+}$ & $0.71 \pm 0.12$ & $0.33 \pm 0.16$ & $0.36 \pm 0.42$ & $0.29 \pm 0.05$ & $0.27 \pm 0.09$ & $0.17 \pm 0.05$ \\
\hline $\mathrm{Ca}^{2+}$ & $4.28 \pm 0.33$ & $3.78 \pm 0.39$ & $2.86 \pm 0.13$ & $7.48 \pm 0.23$ & $3.69 \pm 0.36$ & $1.14 \pm 0.21$ \\
\hline $\mathrm{Mg}^{2+}$ & $2.34 \pm 0.11$ & $2.96 \pm 0.17$ & $1.9 \pm 0.72$ & $3.05 \pm 0.16$ & $2.51 \pm 0.09$ & $0.99 \pm 0.123$ \\
\hline Cation Exchange Capacity (CEC) $\left(\mathrm{cmol} \mathrm{kg}^{-1}\right)$ & $9.49 \pm 0.72$ & $8.31 \pm 0.86$ & $7.85 \pm 0.88$ & $12.82 \pm 0.84$ & $7.63 \pm 0.93$ & $4.16 \pm 0.47$ \\
\hline \multicolumn{7}{|l|}{ Anions $\left(\mathrm{cmol} \mathrm{kg}^{-1}\right)$} \\
\hline $\mathrm{NO}_{3}^{2-}$ & $12.63 \pm 0.19$ & $13.17 \pm 0.8$ & $12.95 \pm 0.4$ & $11.79 \pm 0.73$ & $13.2 \pm 0.92$ & $8.72 \pm 0.64$ \\
\hline $\mathrm{PO}_{4}^{3-}$ & $4.67 \pm 0.38$ & $3.80 \pm 0.42$ & $4.17 \pm 0.42$ & $3.91 \pm 0.55$ & $4.33 \pm 0.49$ & $2.86 \pm 0.46$ \\
\hline $\mathrm{HCO}_{3}^{-}$ & $3.16 \pm 0.27$ & $2.92 \pm 0.33$ & $4.03 \pm 0.28$ & $3.57 \pm 0.22$ & $3.36 \pm 0.29$ & $1.73 \pm 0.31$ \\
\hline Kjeldahl nitrogen $\left(\mathrm{mg} \mathrm{kg}^{-1}\right)$ & $48.6 \pm 2.79$ & $87.8 \pm 3.11$ & $75.6 \pm 2.86$ & $70.5 \pm 2.92$ & $82.4 \pm 3.18$ & $62.59 \pm 2.56$ \\
\hline Organic matter $\left(\mathrm{mg} \mathrm{kg}^{-1}\right)$ & $1.48 \pm 0.17$ & $1.76 \pm 0.19$ & $1.66 \pm 0.11$ & $0.67 \pm 0.13$ & $0.91 \pm 0.17$ & $0.52 \pm 0.11$ \\
\hline Sodium adsorption ratio & $1.19 \pm 0.23$ & $0.67 \pm 0.16$ & $1.77 \pm 0.16$ & $0.89 \pm 0.11$ & $0.58 \pm 0.22$ & $0.63 \pm 0.17$ \\
\hline Texture & Clay loamy & Clay & Clay & Clay & Clay loamy & Clay loamy \\
\hline Sand : Silt : Clay & 26:36:37 & 29:9:62 & $28: 14: 58$ & 20:35:58 & $34: 31: 35$ & 39:41:30 \\
\hline
\end{tabular}

nology is used for the RI values: $<50$ represents low ecological risk, while RI $>600$ is an indicator of very high ecological risk for the water body. This procedure was used to evaluate the ecological risks posed due to anthropogenic heavy metal pollution.

\section{RESULT AND DISCUSSION}

Sediments collected from the Tapi estuary were analyzed for physico-chemical characteristics and the data are presented in Table 3. Heavy metals exhibited higher concentrations in the top layer of sediments and mostly bounded with oxidizable matter (Krupadam et al., 2003). These observations can be attributed to the direct input of pollutants along with oxidizable matter from the ma- jor tributaries leading to enhancing the sedimentation rates in the east side of the estuary (Haake et al., 1993). Table 4 shows the surface distribution of various operationally defined chemical fractions for $\mathrm{Co}, \mathrm{Ni}$ and $\mathrm{Zn}$ along the east side sampling stations (ES-2 and ES-3). As can be seen, the percentages of $\mathrm{Co}, \mathrm{Pb}$ and $\mathrm{Cu}$ in the Fe-Mn oxide and carbonate fractions decreased from eastern sites (ES-2 and ES-3) to southern sites (ES-4 and ES-5) of the estuary. In contrast, $\mathrm{Zn}$ in the residual fraction increased markedly. The result suggests that the decrease of total $\mathrm{Zn}$ concentration could be attributed to the decrease of $\mathrm{Zn}$ in non-residual fractions (e.g., the Fe-Mn oxide, carbonate and exchangeable fractions). Similarly, the decrease of $\mathrm{Cu}$ in the oxidizable fraction is mainly attributed to the decrease of total $\mathrm{Cu}$ concentration from east 


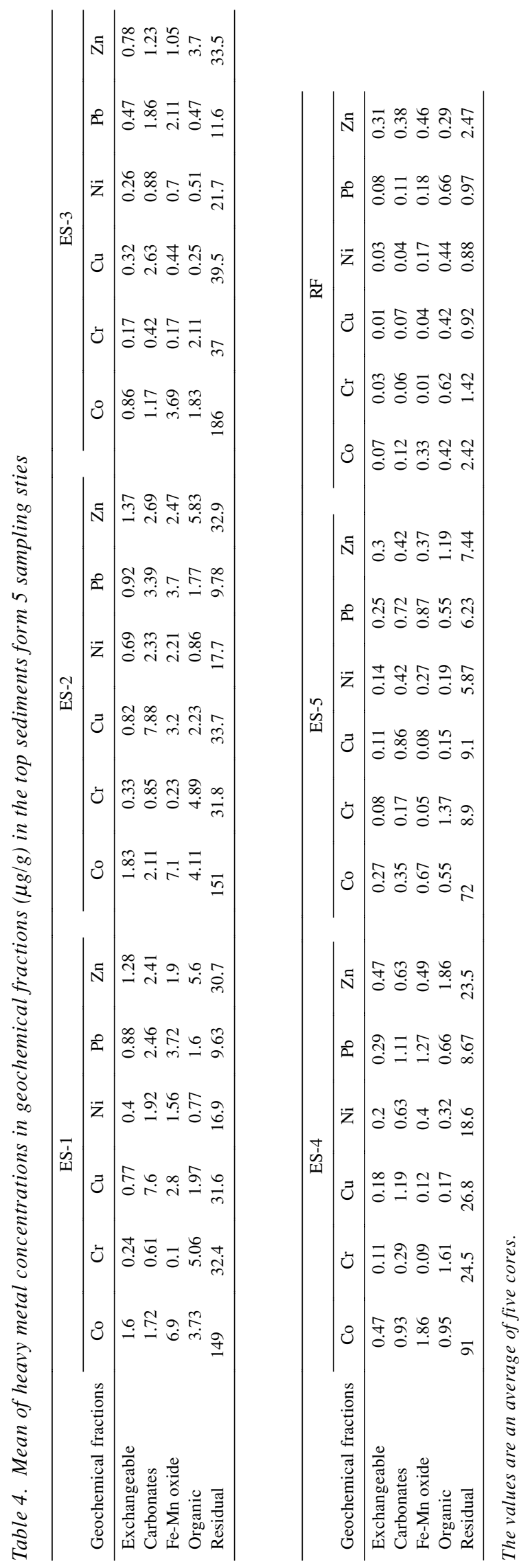

to west of the estuary. Although there were similar distribution patterns of total $\mathrm{Zn}$ and total $\mathrm{Cr}$ to that of total $\mathrm{Ni}$, $\mathrm{Pb}$, spatial patterns in various binding fractions of $\mathrm{Zn}$ and $\mathrm{Cr}$ were less apparent. This may be due to the fact that these two ( $\mathrm{Zn}$ and $\mathrm{Cr}$ ) elements were derived from natural geological sources and generally present as a major portion in the residual fractions.

In estuaries, river water velocity decreases, relative to the river channel areas, as fresh water mixes with seawater. This process would result in deposition of sediments with associated heavy metals. The concentrations of total Co in the top sediments showed a slight decrease from the upstream (ES-1 and ES-2) of the estuary in the south to the sea boundary in the north. This pattern was evident for $\mathrm{Co}$ at the eastern sites i.e., along ES-3 to ES-5 (Fig. 1). Like total Ni, the percentage of Ni bound to the $\mathrm{Fe}-\mathrm{Mn}$ oxide fraction showed a general, distinctive decrease from north to south (Table 4). However, the residual fraction showed an increasing trend in the same direction. There were no significant variations in other Co fractions in the transect. The same decreasing trends of total $\mathrm{Ni}$ concentration and percentage of $\mathrm{Ni}$ in the oxidizable fraction were found along the transect. The percentage of $\mathrm{Ni}$ in the residual fraction tended to increase in the transect. Metals in Fe-Mn oxide fractions may become soluble under changing environmental conditions (e.g., $\mathrm{pH}$ and Eh changes). Hydrous oxides of Fe and $\mathrm{Mn}$ on particulate surfaces are significant carriers for $\mathrm{Zn}$ in aquatic systems (Howard and Vandenbrink, 1999). The present investigation shows that metals adsorbed to $\mathrm{Fe}$ Mn oxides decrease in the order $\mathrm{Co}>\mathrm{Pb}>\mathrm{Cu}>\mathrm{Zn}>\mathrm{Ni}$ $>\mathrm{Cr}$. The sequential extraction results of the current study suggest that $\mathrm{Fe}-\mathrm{Mn}$ oxides may be the main carriers of $\mathrm{Co}, \mathrm{Zn}$ and $\mathrm{Pb}$ from the fluvial environment to the marine body in the estuary. Sediment organic matter is important for $\mathrm{Cr}$ and $\mathrm{Co}$ in these sediments. The present results indicate also that Co has more potential for mobilization from the sediments than $\mathrm{Ni}$ because of its higher concentration in the Fe-Mn oxide fraction. Spatial distribution patterns of $\mathrm{Zn}$ and $\mathrm{Cu}$ in the various fractions also indicate higher potential for mobilization of these metals in the sediments of the eastern side of the estuary than those of western sites, and northern sites higher than southern sites. The higher total metal concentrations and higher percentages of metal in non-residual fractions indicate the anthropogenic inputs to surface sediments from the recent industrial development and urbanization in the surrounding areas. Metallic waste in the form of spent catalyst is especially responsible for sediment metal enrichment. Based on the findings, hypotheses can be developed to explain other processes that may affect heavy metal binding. These may include the tidal suspension and redeposition of clastic material containing bound metals from the tidal flats onto the marsh edge during 
tidal inundation. In tidal flats where sulfate reduction is dominant (Dryssen and Wedborg, 1980; Li et al., 2000) (Table 4), metal ions are more likely to be precipitated as insoluble metal sulphides which are less likely to be flushed through sediment if the extent of water percolation through that sediment is limited (Warren, 1981). These insoluble precipitates may subsequently be remobilized by tidal suspension and redeposition. This process may account for higher heavy metal concentrations at the marsh edge (ES-1 and ES-2) as opposed to the supratidal area at Magdalla (ES-3). This may simply reflect the significantly higher sedimentation rate at the marsh edge at the ES-2 sampling locations of north side of the estuary.

Chromium concentrations at sampling locations ES-1 and ES-2 show enrichment in the top $0-10 \mathrm{~cm}$ of the tidal area but a decrease in the top $<10 \mathrm{~cm}$ of the marsh edge. The formation of a chromium-chloride complex, which is less stable than a chromium humic acid complex, would facilitate greater mobility of chromium in this area of frequent inundation where changes in salinity are common. This theory is supported by the lower correlation between chromium and clay and organic carbon content in the estuary.

Another physico-chemical process may be demonstrated by the manganese concentrations, which are lowest in the supratidal areas (ES-4 and ES-5) for both sites, with the tidal flat concentrations being greater than those of the tidal marsh edge (ES-1 and ES-2). In supratidal settings, water-table fluctuations facilitate changes in redox conditions in the upper levels of the profile, with relatively high freshwater input owing to the high rainfall, reducing salinity. Manganese oxides are reduced in anoxic sediments to the more soluble $\mathrm{Mn}^{2+}$ form, which can enter the interstitial waters of the sediment (Beeftink and Rozema, 1988). The anoxic conditions present in tidal flats may facilitate the reduction of manganese removal. Furthermore, the manganese enrichment seen in the younger sediments of all cores may be partly re-precipitated $\mathrm{Mn}^{2+}$, presumably in the form of insoluble oxides and hydroxides diffusing to the surface (Table 4). A similar transient storage of manganese and iron and higher concentrations in surface layers has been demonstrated in the other tidal marshes (McCaffrey and Thompson, 1980; Casas and Crecelius, 1994). In tidal marshes, redox conditions will fluctuate with varying water levels, resulting in different usage of electron acceptors, and therefore different ions will be released to the interstitial waters (Beeftink and Rozema, 1988). The fact that manganese concentrations at these sites are high compared to background concentrations could suggest that two processes may be affecting the heavy metal distribution in near surface sediments: i.e., in addition to the possibility of digenetic mobilization of manganese in response to
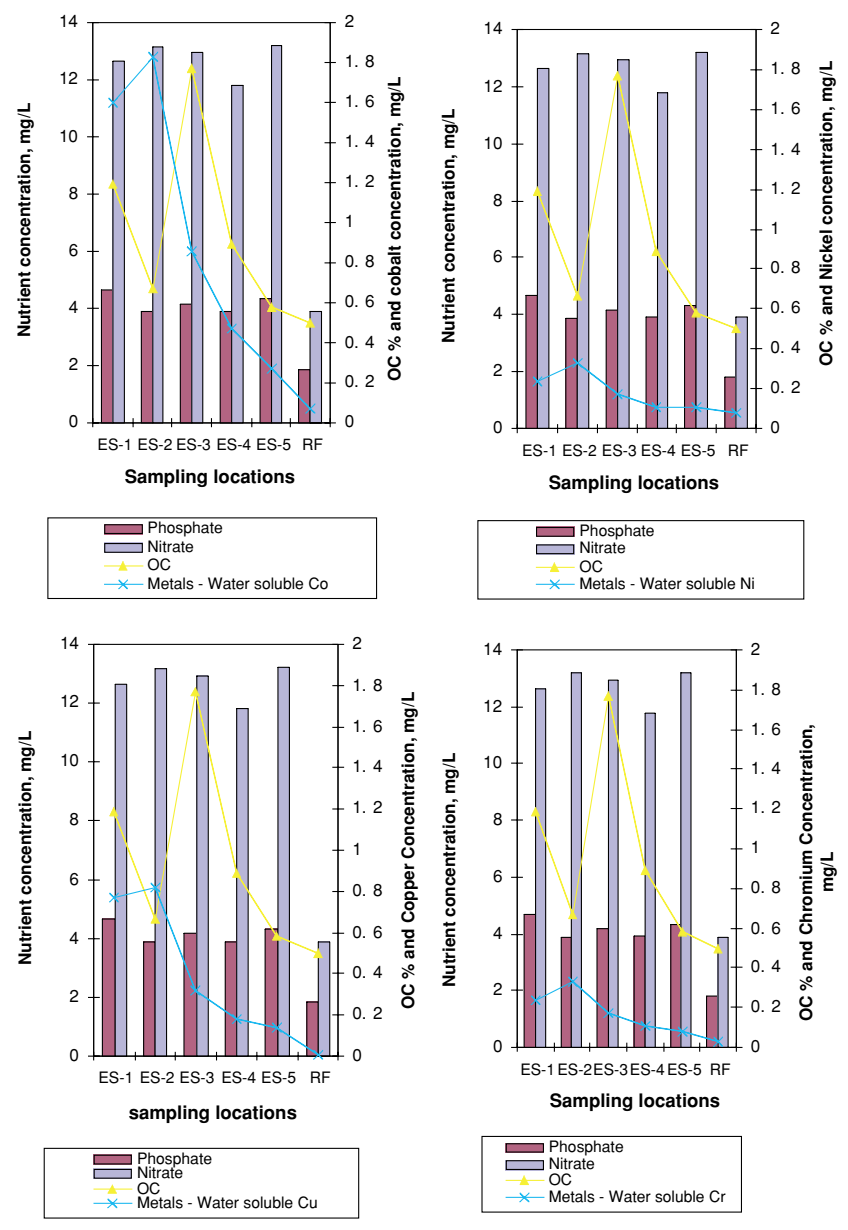

Fig. 2. Relationship between reactive metal fractions with nutrients.

changes in redox potential, we may also find an increased anthropogenic input.

A significant amount of $\mathrm{Zn}$ was associated with the non-residual fractions in sediments studied, indicating that this metal was potentially more bioavailable than other metals examined. Copper was found primarily in the residual or carbonate bound fractions in most of the sediments. Little Co and $\mathrm{Ni}$ were found in sediments in exchangeable form. Overall the order of concentrations was $\mathrm{Co}>\mathrm{Ni}>\mathrm{Zn}>\mathrm{Cu}$. Among the five sediments tested ES-2 and ES-3 were the most contaminated sediments with the four metals studied. The distribution of $\mathrm{Zn}$ in various chemical fractions was dependent on the total $\mathrm{Zn}$ concentration in sediments, whereas the distribution of $\mathrm{Cu}, \mathrm{Co}$ and $\mathrm{Ni}$ in different fractions depends on respective total metal concentrations in the sediments.

The sequential extraction results showed that $\mathrm{Zn}, \mathrm{Ni}$, and Co in top sediments were mainly associated with the residual and $\mathrm{Fe}-\mathrm{Mn}$ oxide fractions. The $\mathrm{Zn}$ bound to the 


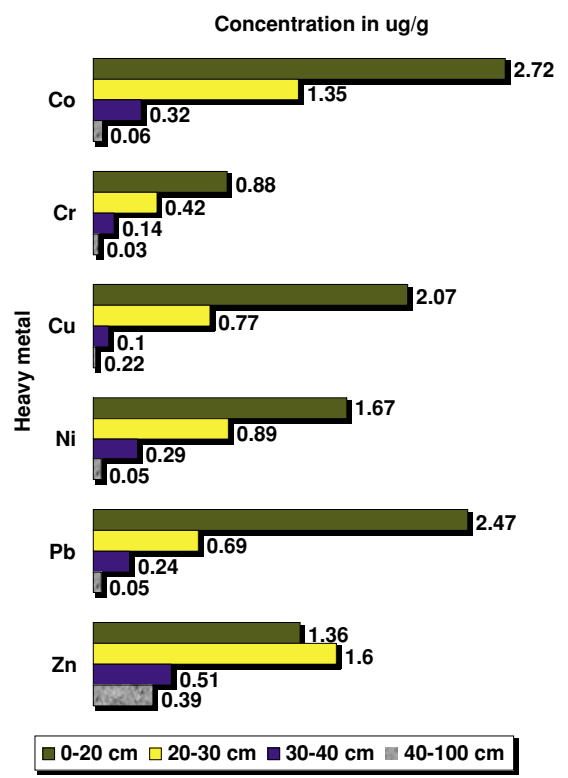

Fig. 3. Depth profile of heavy metal distribution in the Tapi Estuary.

$\mathrm{Fe}-\mathrm{Mn}$ oxides fraction had significant relationships with reducible $\mathrm{Mn}$ and reducible $\mathrm{Fe}$ concentrations (Fe-Mn oxides), suggesting that Fe-Mn oxides may be the main carriers of $\mathrm{Zn}$ from the fluvial environment to the marine body. The major geochemical phases for $\mathrm{Cu}$ were $\mathrm{Fe}-\mathrm{Mn}$ oxide, carbonate and residual fractions. There was a significant relationship between $\mathrm{Cu}$ bound to the oxidizable fraction and sediment organic content (Table 4). The correlation between reactive metals with nutrients and organic matter is depicted in Fig. 2. Depth profiles of heavy metal concentrations representing surface enrichment up to $30 \mathrm{~cm}$ from the surface followed by $40-100$ $\mathrm{cm}$ with no trend, i.e., increase or decrease, observed suggesting that the values at depth represent geological background (Fig. 3). The metals in the non-residual fractions ( $\mathrm{Zn}$ in the $\mathrm{Fe}-\mathrm{Mn}$ oxide fraction and $\mathrm{Cu}$ in the oxidizable fraction) showed a general distinctive decrease from the western sites to the eastern sites of the estuary, and from upstream in the north to the sea in the south. The results may reflect the anthropogenic inputs of heavy metals to the sediments from recent rapid industrial development and urbanization in the surrounding area.

To estimate the extent of heavy metal contamination associated with the sediments of the estuary, the $I_{\text {geo }}$ of six metals were calculated (Table 5). According to the classification of $\mathrm{I}_{\text {geo }}$ suggested by Müller (1979), the highest level of contamination, with an index value of 6 (very strong contamination), reflects 100 -fold enrichment of metals, compared in their background values. In the Tapi estuarine sediments, $\mathrm{Zn}$ and $\mathrm{Pb}$ at sampling locations ES4 and ES-5 can be regarded as being strongly contami-
Table 5. Geoaccumulation and enrichment factors of heavy metals in the sediment

\begin{tabular}{|c|c|c|c|c|c|}
\hline Heavy metal & ES-1 & ES-2 & ES-3 & ES-4 & ES-5 \\
\hline \multicolumn{6}{|l|}{ Co } \\
\hline $\mathrm{C}_{\mathrm{n}}$ & 162 & 166 & 193 & 95 & 73.8 \\
\hline $\mathrm{B}_{\mathrm{n}}$ & 3.36 & 3.45 & 3.12 & 2.96 & 2.90 \\
\hline$I_{\mathrm{geo}}$ & 1.46 & 1.43 & 1.63 & 1.49 & 1.43 \\
\hline $\mathrm{EF}$ & 22.8 & 26 & 12 & 6.7 & 3.8 \\
\hline \multicolumn{6}{|l|}{$\mathrm{Cr}$} \\
\hline $\mathrm{C}_{\mathrm{n}}$ & 38.4 & 38.1 & 39.9 & 26.6 & 10.5 \\
\hline$B_{n}$ & 2.14 & 2.25 & 1.98 & 1.94 & 1.85 \\
\hline$I_{\text {geo }}$ & 1.65 & 1.56 & 1.98 & 1.63 & 1.23 \\
\hline $\mathrm{EF}$ & 8 & 11 & 5.6 & 3.6 & 2.6 \\
\hline \multicolumn{6}{|l|}{$\mathrm{Cu}$} \\
\hline $\mathrm{C}_{\mathrm{n}}$ & 44.7 & 47.8 & 43.1 & 28.5 & 10.3 \\
\hline $\mathrm{B}_{\mathrm{n}}$ & 1.46 & 1.55 & 1.39 & 1.26 & 1.15 \\
\hline$I_{\text {geo }}$ & 2.51 & 2.56 & 2.61 & 2.57 & 1.96 \\
\hline $\mathrm{EF}$ & 77 & 82 & 32 & 18 & 11 \\
\hline \multicolumn{6}{|l|}{$\mathrm{Ni}$} \\
\hline$C_{n}$ & 21.5 & 23.8 & 24 & 20 & 6.89 \\
\hline$B_{n}$ & 1.56 & 1.68 & 1.5 & 1.46 & 1.29 \\
\hline$I_{\mathrm{geo}}$ & 1.90 & 1.82 & 2.05 & 1.98 & 1.44 \\
\hline $\mathrm{EF}$ & 13 & 23 & 8.7 & 6.7 & 4.7 \\
\hline \multicolumn{6}{|l|}{$\mathrm{Pb}$} \\
\hline$C_{n}$ & 18.79 & 19.6 & 16.6 & 12 & 8.62 \\
\hline$B_{n}$ & 2 & 2.35 & 1.92 & 1.85 & 1.73 \\
\hline$I_{\text {geo }}$ & 1.42 & 1.22 & 1.41 & 1.3 & 1.2 \\
\hline $\mathrm{EF}$ & 11 & 11.5 & 5.9 & 3.6 & 3 \\
\hline \multicolumn{6}{|l|}{$\mathrm{Zn}$} \\
\hline$C_{n}$ & 41.9 & 45.2 & 40.3 & 27 & 9.72 \\
\hline $\mathrm{B}_{\mathrm{n}}$ & 3.91 & 4.11 & 3.86 & 3.73 & 3.52 \\
\hline$I_{\mathrm{geo}}$ & 0.92 & 0.89 & 0.92 & 0.85 & 0.62 \\
\hline $\mathrm{EF}$ & 4.1 & 4.5 & 2.5 & 1.5 & 1 \\
\hline
\end{tabular}

The values are an average of five cores.

nated (index value of 5/6); the $\mathrm{Cu}, \mathrm{Cr}$ and $\mathrm{Ni}$ are at moderately contaminated level $(2 / 3)$. The average $\mathrm{I}_{\text {geo }}$ of six metals in the sediments from the middle of the estuary is 3.67 and is larger than the estuary mouth (1.24) and seaside sampling locations (2.33). This shows that the middle of the estuary is strongly contaminated with $\mathrm{Zn}, \mathrm{Pb}$, $\mathrm{Co}$ and $\mathrm{Ni}$, while other metals fall in class 2 , indicating moderate pollution. The enrichment factors were useful in determining whether the metal concentrations or elemental concentrations were mostly lithogenic in origin or were anthropogenically introduced. For $\mathrm{Co}$ and $\mathrm{Ni}$, the enrichment factors were correlated with Fe-Mn oxides. This implies that these metals are mostly lithogenic in origin and are not anthropogenically introduced. In this study, $\mathrm{Zn}, \mathrm{Pb}$, and $\mathrm{Cr}$ were not correlated with bottom layers and had a high enrichment factor (up to 60 times) representing the influence of anthropogenic activities. In 

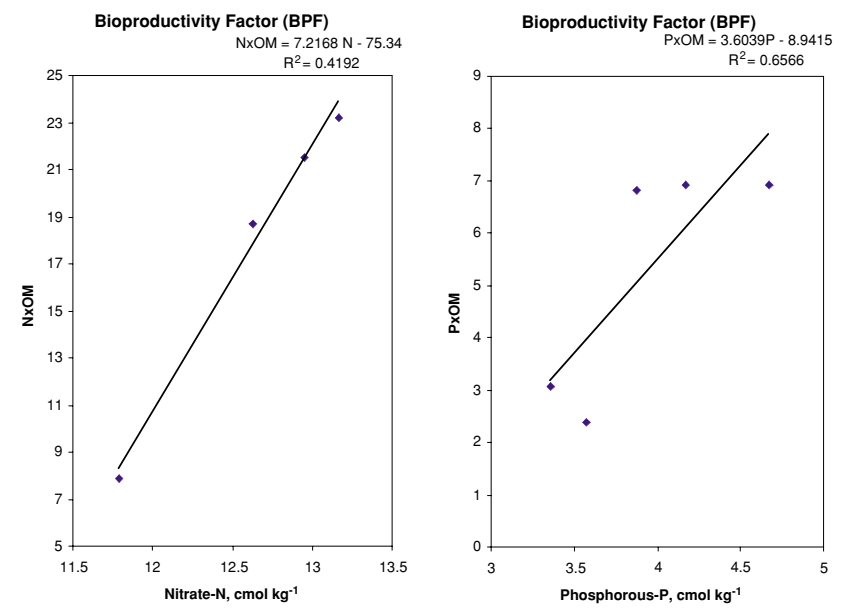

Fig. 4. Bioproductivity factors.

the present study, the contamination factor was assumed to be equal to the sum of heavy metal concentrations in the mobile phases of estuary samples divided by the residual phase content. The highest value of $\mathrm{Cf}^{\mathrm{i}}$ for each individual metal among the sampling divided by the residual metal among the sampling stations was chosen. The bioproduction factor (BPF) value was obtained in an indirect way. In addition to $\mathrm{N}$ and oxidizable matter (OM), phosphate showed a better relationship with bioproductivity. Perhaps as a result of lower salinity, phosphates are better indicator of bioproductivity than nitrate$\mathrm{N}$. This is demonstrated by the non-linearity of nitrate-N with organic matter where as phosphate-P is a dominant nutrient representing better linearity with organic matter (Fig. 4). This approach is a rather conservative one. As has already been demonstrated, metals in the mobile phases will not show the same potential for mobilization. The value of 11.2 for BPF was adopted and it is proposed that this choice would be an underestimation of the parameter leading to a rather conservative estimate of the associated ecological risk index. Also we decided to use the same equation of $\operatorname{Tr}^{\mathrm{i}}$ for $\mathrm{Zn}$ as for $\mathrm{Cu}$, Co and $\mathrm{Ni}$. Figure 5 shows the results obtained. As has been suggested by the fractionation studies, $\mathrm{Zn}$ produced the highest individual ecological risk among the studied metals and, because of this finding, would be the critical element concerning ecological hazard in the Tapi estuary. On the other hand, the system is exposed to moderate to high ecological risk $(\mathrm{RI}=250-320)$ with respect to the studied heavy metal pollution. Based on the correlations between risk factor and geoaccumulation, the major driving factor for toxicity is the soluble fractions of total metal content. Higher geoaccumulation index showing lower ecological risk factor may be due to metal immobilization. The enrichment factor is representing no relationship with RF. The adopted ecological risk assessment
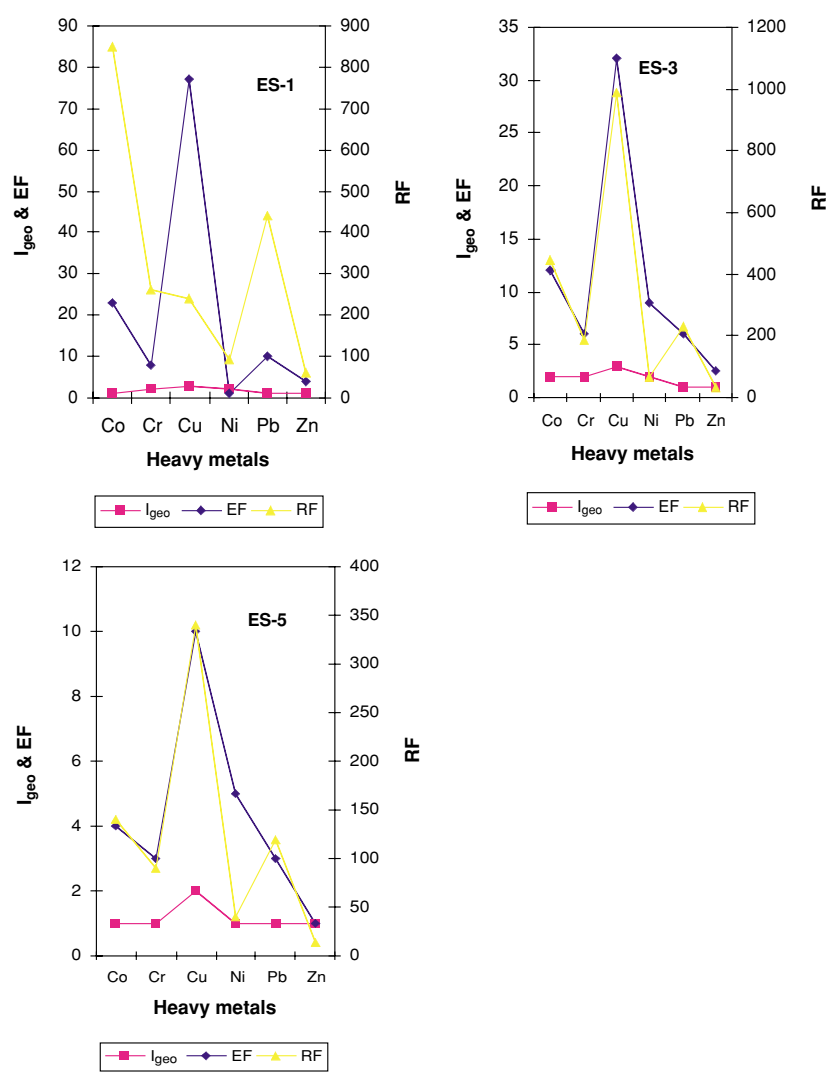

Fig. 5. Ecological risk factors.

methodology showed that the system is exposed to a high ecological risk due to metal pollution and that $\mathrm{Co}, \mathrm{Ni}$ and $\mathrm{Cu}$ would be the metals of prime concern among those studied. These results are in good agreement with the prediction made by means of the sediment fractionation study.

Acknowledgments-The authors express their gratitude to Dr. Sukumar Devotta, Director, National Environmental Engineering Research Institute, India for his encouragement and support in this research program. The authors wish to thank reviewers of this article for providing valuable comments. We are grateful to Professor Y. Anjaneyulu, Director, Institute of Science \& Technology, Jawaharlal Nehru Technological University, India for helpful advice and giving constructive criticism.

\section{REFERENCES}

Beeftink, W. G. and Rozema, J. (1988) The nature and functioning of saltmarshes. Pollution of the North Sea, An Assessment (Salomans, W. and Forstner, U., eds.), 59-87, Springer, Berlin.

Casas, A. M. and Crecelius, E. A. (1994) Relationship between acid volatile sulfide and the toxicity of zinc, lead and copper in marine sediments. Environmental Toxicology and 
Chemistry 13(3), 529-536.

CPCB (Central Pollution Control Board) (1994) Assessment and development of study of river basin series: ADSORBS/ 4/1980-81.CBPC-WP, 1-52, New Delhi.

De Groot, A. J., Salmons, W. and Allersma, E. (1976) Processes affecting heavy metals in estuarine sediments. Estuarine Chemistry (Burton, J. D. and Liss, P. S., eds.), 131153, Academic Press, London.

Dean, W. E., Jr. (1974) Determination of carbonate and organic matter in calcareous sediments and sedimentary rocks by loss on ignition comparison with other methods. J. Sedimentation and Petrology 44, 242-248.

Dryssen, D. and Wedborg, M. (1980) Major and minor elements, chemical speciation in estuarine waters. Chemistry and Biogeochemistry of Estuaries (Olausson, E. and Cato, I., eds.), 71-119, Wiley, Chichester.

Gupta, S. K. and Chen, K. Y. (1975) Partitioning of trace metals in selective chemical fractions of near shore sediments. Environ. Lett. 10, 129-158.

Hakanson, L. (1980) An ecological risk index for aquatic pollution control, a sediment logical approach. Wat. Research 14, 975-1001.

Hakee, B., Bartsch, M., Rixen, R., Ramaswamy, V., Nair, R. R. and Curry, W. B. (1993) Seasonality and interannual variability of particle fluxes to the Arabian sea. Deep-Sea Res. 40, 1323-1343.

Howard, J. L. and Vandenbrink, W. J. (1999) Sequential extraction analysis of heavy metals in sediments of variable composition using nitrilotriacetic acid to counteract resorption. Environ. Pollut. 106, 285-292.

Jantschik, R., Nyfleler, F. and Donard, O. F. X. (1992) Marine particle size measurement with a stream scanning laser system. Mar. Geol. 106, 239-250.

Krupadam, R. J., Sarin, R. and Anjaneyulu, Y. (2003) Distribution of trace metals and organic matter in the sediments of Godavari estuary of Kakinada bay, East Cost of India. Water, Air and Soil Pollut. 150, 299-318.

Li, X. D., Wai, O. W. H., Li, Y. S., Coles, B. J., Ramsey, M. H. and Thornton, I. (2000) Heavy metal distribution in sediment profiles of the Pearl River estuary, South China. Appl. Geochem. 15, 567-581.

McCaffrey, R. J. and Thompson, J. (1980) A record of the accumulation of sediments and trace metals in a Connecticut saltmarsh. Advances in Geophysics (Landsberg, H. E., ed.), 265-272. Academic Press, New York.

Müller, G. (1979) Schwermettalle in den sedimenten des RheinsVeranderungen seit 1971. Umschau Wissensch Tech. 79, 778-783.

Nelson, N. D. and Sommers, L. E. (1982) Total carbon, organic carbon and matter. Methods of Soil Analysis, Part 2: Chemical and Microbiological Properties (Page, A. L., ed.), 538588.

Raad, A. A. (1978) Carbonates. Manual of Soil Sampling and Methods of Analysis (McKeange, J. A., ed.), 2nd eds., Can. Soc. Soil. Sci., Ottawa.

Salomons, W. and Forstner, U. (1984) Metals in the Hydrocycle. Springer, Berlin.

Soto-Jimenez, M. F., Paez-Osuna, F. and Ruiz-Fernandez, A. C. (2003) Geochemical evidences of the anthropogenic alterations of trace metal composition of the sediments of Chiricahueto marsh (SE Gulf of California). Environ. Pollut. 125, 423-432.

Sposito, G., Lund, J. and Chang, A. C. (1982) Trace metal chemistry in arid-zone field soils enriched with sewage sludge. I. Fractionation of $\mathrm{Ni}, \mathrm{Cu}, \mathrm{Zn}, \mathrm{Cd}$ and $\mathrm{Pb}$ in solid phase. Soil Sci. Soc. Am. J. 46, 260-264.

Tessier, A., Campbell, P. G. C. and Bisson, M. (1979) Sequential extraction procedure for the speciation of trace metals. Anal. Chem. 51, 244-251.

Tessier, A., Campbell, P. G. C. and Bisson, M. (1980) Trace metal speciation in the Yamask and St. Francois rivers (Quebec). Can. J. Earth Sci., 17,

Wang, P., Qu, E., Li, Z. and Shuman, L. M. (1997) Fraction and availability of nickel in soil amended with sewage or sewerage sludge. J. Environ. Quall. 26, 795-801.

Warren, L. J. (1981) Contamination of sediments by lead, zinc and cadmium. A review. Environ. Pollut. B2, 401-436.

Yong, S. D., Tye, A., Carstensen, A., Resende, L. and Crout, N. (2000) Methods for determining liable cadmium and zinc in soils. Eu. J. Soil Sci. 51, 129-136.

Yu, K.-S., Tsai, L.-J., Chen, S.-H. and Ho, S.-T. (2001) Correlation analysis of binding behaviour of heavy metals with sediment matrices. Water Res. 35(10), 2417-2428.

Zoumis, T., Schmidt, A., Grigorova, L. and Calmano, W. (2001) Contaminants in sediments: remobilization and demobilization. Sci. Total Environ. 266, 195-202. 